\title{
Detection of the oyster parasite Bonamia ostreae by fluorescent in situ hybridization
}

\author{
Ryan B. Carnegie ${ }^{1,3, *}$, Bruce J. Barber ${ }^{1}$, Daniel L. Distel ${ }^{1,2}$ \\ ${ }^{1}$ School of Marine Sciences, and ${ }^{2}$ Department of Biochemistry, Microbiology, and Molecular Biology, 5735 Hitchner Hall, \\ University of Maine, Orono, Maine 04469-5735, USA
}

${ }^{3}$ Present address: Aquaculture Genetics and Breeding Technology Center, Virginia Institute of Marine Science, Gloucester Point, Virginia 23062, USA

\begin{abstract}
Bonamia ostreae is an economically significant protistan parasite of the flat oyster Ostrea edulis in Europe and North America. Management of this parasite depends partly upon its reliable identification in wild and aquacultured oyster populations, but B. ostreae is small and difficult to detect by traditional microscopic methods. We designed a fluorescent in situ hybridization (FISH) assay to sensitively detect $B$. ostreae in standard histopathological sections of $B$. ostreaeinfected oysters using fluorescently labeled DNA oligonucleotide probes. Hybridization using a cocktail of 3 presumptively B. ostreae-specific, fluorescein iso(thio)cyanate (FITC)-labeled oligonucleotides produced an unambiguous staining pattern of small green rings inside infected oyster hemocytes that was easily distinguished from host tissue background. This pattern is diagnostic for B. ostreae. A negative control cocktail of oligonucleotides containing 2 mismatches relative to target sequences, on the other hand, failed to hybridize at all. B. ostreae-specific probes did not cross-react with a related protist, Haplosporidium nelsoni.
\end{abstract}

KEY WORDS: Bonamia ostreae $\cdot$ Ostrea edulis $\cdot$ Fluorescent in situ hybridization

\section{INTRODUCTION}

Bonamia ostreae (Pichot et al. 1980) is a protistan parasite of Ostrea edulis Linné, a commercially important flat oyster that occurs widely in Europe and locally on both coasts of North America. It proliferates within oyster hemocytes (Balouet et al. 1983), often resulting in massive inflammation and death of its host (Bucke \& Feist 1985). A haplosporidian protist (Pichot et al. 1980, Perkins 1990, Carnegie et al. 2000), B. ostreae was described after causing catastrophic oyster mortality in 1979 in Brittany, France (Comps et al. 1980, Pichot et al. 1980), but was first observed in California, USA a decade earlier (Katkansky et al. 1969, Elston et al. 1986). It now occurs in Europe from Ireland to Spain and in California, Washington, and Maine, USA (Comps et al. 1980, Pichot et al. 1980, Bucke \& Feist 1985, van Banning 1985, Elston et al. 1986, Friedman et al. 1989, McArdle et al. 1991, Montes et al. 1991,
Barber \& Davis 1994, Friedman \& Perkins 1994, Zabaleta \& Barber 1996). The disease B. ostreae causes, bonamiosis, is notifiable to the Office International des Epizooties (OIE), and is a serious threat to flat oyster aquaculture.

Bonamia ostreae transmission is direct (Elston et al. 1987). Bonamiosis outbreaks in Europe began when $B$. ostreae was transmitted to naïve French $O$. edulis populations from infected juvenile $O$. edulis imported commercially from California (Elston et al. 1986). This may not have occurred if the oysters had been screened before transfer, $B$. ostreae had been recognized as an infectious agent, and the transfer had been denied. Bonamia ostreae is not easily detected, however. Because it is small (2 to $3 \mu \mathrm{m}$ in diameter; Pichot et al. 1980), it may be overlooked in microscopic examinations of lightly infected oysters (Bucke \& Feist 1985). Such oysters may seem healthy. Early B. ostreae infections are typically focal (Bucke \& Feist 1985, 
Bucke 1988); foci may be missed during sampling. Recently developed PCR assays for B. ostreae (Carnegie et al. 2000, Cochennec et al. 2000), on the other hand, may detect the parasite too sensitively. Degraded or non-viable pathogen DNA may generate false positive PCR results. False negative results, as with histopathology, may arise because of sampling error (Burreson 2000).

In situ hybridization (ISH) is a powerful complement to traditional and PCR-based detection methods. It combines advantages of both. Like traditional histopathology (i.e. the microscopic examination of fixed and stained tissue sections), ISH reveals the tissue location of an infection and the host response. Like PCR, ISH is specific and very sensitive. Successful hybridization provides an unambiguous phylogenetic confirmation that a specific pathogen is associated with a specific host tissue. The usefulness of ISH goes beyond routine diagnostics. An ISH for Haplosporidium nelsoni (Stokes \& Burreson 1995), for example, has been used with PCR in attempts to resolve this oyster parasite's life cycle (Stokes et al. 1997), and was used to discover its geographic source (Burreson et al. 2000). An ISH for Bonamia ostreae, similarly, could confirm routine PCR results, illuminate $B$. ostreae's life cycle and transmission dynamics, and resolve its transplantation history. The development of a fluorescent ISH (FISH) for B. ostreae was the objective of this project.

\section{MATERIALS AND METHODS}

Sample collection and histological processing. Seventy Ostrea edulis were collected at Gun Point Creek, Maine, USA $\left(43^{\circ} 46^{\prime} 28^{\prime \prime} \mathrm{N}, 69^{\circ} 56^{\prime} 50^{\prime \prime} \mathrm{W}\right)$ on 4 June 2000. Hemolymph was non-destructively drawn from the adductor muscle of each, diluted in artificial seawater $(\sim 1: 10 ; 30 \%)$, and placed on a glass slide. Hemocytes adhering after $10 \mathrm{~min}$ were fixed and stained using Hemostat solutions (Fisher Scientific; see Culloty \& Mulcahy 1996, Zabaleta \& Barber 1996). Slides were screened for Bonamia ostreae using a compound microscope at 400 magnification until 5 oysters with abundant $B$. ostreae were identified. These individuals were sacrificed and fixed whole in Davidson's Solution (Shaw \& Battle 1957) for $24 \mathrm{~h}$. Transverse sections ( $\sim \mathrm{mm}$ ) posterior to the palps were dehydrated, cleared, and embedded in paraffin. Serial sections $(5 \mu \mathrm{m})$ were cut from these blocks and dried at 50 to $55^{\circ} \mathrm{C}$ on 3 -aminopropyltriethoxysilane (APTS)-treated slides (Schwarzacher \& Heslop-Harrison 2000). The first slide in each series was stained with hematoxylin and eosin (H\&E) for standard histopathological evaluation. Others were used for FISH. Thin sections $(5 \mu \mathrm{m})$ of paraffin-embedded Crassostrea virginica infected with Haplosporidium nelsoni were included to test for cross-reactivity of the $B$. ostreae-specific probes.

Design and preparation of probes. An alignment of haplosporidian and oyster SSU rDNA gene sequences was constructed for DNA oligonucleotide probe selection. Bonamia ostreae (GenBank accession number AF262995), Haplosporidium nelsoni (U19538), H. costale (U20858), H. louisiana (U47851), Minchinia teredinis (U20319), Urosporidium crescens (U47852), and Ostrea edulis (U88709) sequences were aligned using the program Se-Al (Oxford University Evolutionary Biology Group). Seven probes were designed. UME-BO-1 (5'-CGAGGCAGGGTTTGT-3'), UME-BO-2 (5'-GGGTCAAACTCGTTGAAC-3'), and UME-BO-3 (5'-CGCTCTTATCCACCTAAT-3') in theory were specific for B. ostreae. They composed a multi-oligoprobe cocktail, an effective way to increase sensitivity without sacrificing specificity (Trembleau \& Bloom 1995). Potential cross-reactivity of these probes with other SSU rDNA sequences was discounted after a GenBank BLAST search for the probes and their targets revealed no close matches. Negative control probes UME-BO-1M (5'-CGAGCCAGGCTTTGT-3'), UME-BO-2M (5'-GGCTCAAACTCCTTGAAC-3'), and UME-BO-3M (5'-CCCTCTTATCCTCCTAAT-3') each differed from corresponding $B$. ostreae-specific probes by 2 substitutions. Thus, they were slightly mismatched to theoretical target sequences. UME-OE-385 (5'-TCATGCTCCCTCTCCGG-3') was a positive control oligonucleotide designed to bind to both $O$. edulis and B. ostreae.

The probes were synthesized by Operon Technologies). Each carried a $5^{\prime}$ fluorescein iso(thio)cyanate label (FITC; absorbance $=490$ to $496 \mathrm{~nm}$; emission $=514$ to $521 \mathrm{~nm}$ ). All probes were purified using thinlayer chromatography (TLC; plate: $20 \mathrm{~cm} 20 \mathrm{~cm}$ $250 \mu \mathrm{m}$ Whatman PE SIL G/UV, polyester-backed and silica-coated; running buffer: $55 \mathrm{ml} \mathrm{n}$-propanol, $35 \mathrm{ml}$ ammonium hydroxide, $10 \mathrm{ml} \mathrm{H}_{2} \mathrm{O}$ ) and resuspended in Tris-EDTA $(\mathrm{pH}=7.4)$.

FISH. Our FISH methodology was derived from published ISH protocols (Dubilier et al. 1995, Stokes \& Burreson 1995, Stokes et al. 1995). Four consecutive Ostrea edulis sections and 2 Crassostrea virginica sections were deparaffinized in xylene (3 10 min), rehydrated through a descending ethanol series $(100,95$, 80 and $70 \%$ for $10 \mathrm{~min}$ each), and equilibrated in phosphate-buffered saline (PBS; once for $10 \mathrm{~min}$, once for $5 \mathrm{~min}$ ). The sections were then digested with Proteinase $\mathrm{K}\left(100 \mu \mathrm{g} \mathrm{ml} \mathrm{m}^{-1}\right.$ in PBS for $15 \mathrm{~min}$ at $37^{\circ} \mathrm{C}$, followed by a wash in PBS plus $0.2 \%$ glycine for 5 min); acetylated using acetic anhydride (5\% [v/v] in $0.1 \mathrm{M}$ triethanolamine- $\mathrm{HCl}[\mathrm{pH}$ 8.0] for $10 \mathrm{~min}$ at room temperature, followed by a wash in PBS for 10 min; see Schwarzacher \& Heslop-Harrison 2000); and equilibrated in 5 SET (750 mM NaCl, $6.4 \mathrm{mM}$ 
EDTA, $100 \mathrm{mM}$ Tris base) (10 min at room temperature). Excess SET was drained off, and $200 \mu \mathrm{l}$ of prehybridization buffer (5 SET, $0.02 \%$ bovine serum albumin, $0.025 \%$ sodium dodecyl sulphate [SDS]) was added to each section. After incubation for $30 \mathrm{~min}$ at $45^{\circ} \mathrm{C}$, the prehybridization buffer was drained off and replaced with 10 to $12 \mu \mathrm{l}$ of prehybridization buffer containing 2 to $10 \mathrm{ng}^{-1}$ of the appropriate oligonucleotide(s). One $O$. edulis section received theoretically Bonamia ostreae-specific probes UME-BO-1, UME-BO-2, and UME-BO-3; a second received mismatched probes UME-BO-1M, UME-BO-2M, and $\mathrm{UME}-\mathrm{BO}-3 \mathrm{M}$; a third received no probe; and a fourth received the control probe UME-OE-385. The C. virginica sections (Haplosporidium nelsoni controls) received probes UME-BO-1, UME-BO-2, and UMEBO-3. The sections were coverslipped with parafilm and incubated overnight in humid chambers at $45^{\circ} \mathrm{C}$. They were washed the next day in 0.2 SET (3 5 $\min$ at $42^{\circ} \mathrm{C}$ ), air dried, and then covered using Vectashield Mounting Medium (Vector Laboratories) and glass coverslips.

Slides were examined (600 to 1000 ) using a Nikon Labophot-2 epifluorescent microscope with a dual FITC-Texas Red filter. Specific fluorescence patterns were expected to result from the 5 experimental conditions. Binding of the Bonamia ostreae-specific probes to $B$. ostreae rRNA was expected to result in the appearance of green rings of 2 to $4 \mu \mathrm{m}$ outside diameter within oyster hemocytes. The mismatched probe condition would display a near or complete absence of green fluorescence. The no probe condition and the Haplosporidium nelsoni control would show no green fluorescent signal (orange background alone). Finally, in the positive control, all tissues would exhibit green fluorescence.

Fluorescent images were captured on $35 \mathrm{~mm}$ slide film and scanned. The images were prepared for publication using Jasc Paint Shop Pro Version 7.00 (Jasc Software). Diameters of stained structures were estimated by calculation from pixel measurements using this software.

\section{RESULTS}

Probes UME-BO-1, UME-BO-2, and UME-BO-3 hybridized to Bonamia ostreae rRNA (Fig. 1A). Small FITC-stained objects occurred in many hemocytes in all tissues, and were sometimes free in hemolymph sinuses. Each resembled a small green ring, as green fluorescence surrounded an eccentric dark region. They resembled rings because the labeled probes were concentrated at the ribosomes within the cytoplasm, surrounding the eccentric $B$. ostreae cell nucleus. The distribution of these small green rings precisely matched the distribution of $B$. ostreae cells observed in the H\&E-stained section. The outside diameter of these rings $(2.4$ to $5.6 \mu \mathrm{m})$ also conformed to that expected for $B$. ostreae.

Negative control treatments showed only an orange background autofluorescent signal. Fig. 1B illustrates the level of background autofluorescence in the absence of probes. The mismatched-probe control treatment (Fig. 1C) and the Haplosporidium nelsoni control treatment (Fig. 1D) resembled the no probe condition in Fig. 1B. They displayed none of the green fluorescence characteristic of probe binding. The failure of mismatched probes UME-BO-1M, UME-BO-2M, and UME-BO-3M to hybridize (Fig. 1C) indicated that the theoretically Bonamia ostreae-specific probes UMEBO-1, UME-BO-2, and UME-BO-3 hybridized to specific target sequences. The failure of UME-BO-1, UME-BO2, and UME-BO-3 to hybridize to H. nelsoni (Fig. 1D) confirmed that these target sequences were, if not unique to $B$. ostreae, restricted to certain haplosporidians. Importantly, the specific probes failed to hybridize to one of B. ostreae's closest phylogenetic relatives.

\section{DISCUSSION}

This FISH assay for Bonamia ostreae provided significant advantages over traditional histopathological techniques. The assay generated unambiguous signs when B. ostreae was present. B. ostreae-specific fluorescence possessed a characteristic color, shape, and size, and occurred in a specific tissue. It was green, ring-shaped, and small (2.4 to $5.6 \mu \mathrm{m})$, and was primarily observed inside hemocytes. The color reflected specific binding of the FITC-conjugated probes; the shape reflected the cytoplasmic location of the ribosomes to which the probes hybridized; and the size reflected the actual diameter of $B$. ostreae cells. The tissue location of the fluorescence reflected the tissue specificity documented for $B$. ostreae itself (Balouet et al. 1983). Unambiguous B. ostreaespecific staining possessed all 4 traits.

Traditional histopathological detection of Bonamia ostreae depends on 3 possible observations: small size, a 'fried egg' appearance to the presumptive B. ostreae cells, and association of these cells with hemocytes (Bower et al. 1994). B. ostreae cells are easily observed when they are numerous; for example, in oysters with systemic infections. In oysters with light or prepatent infections, however, small B. ostreae cells may be mistaken for routine intracytoplasmic inclusions (Bucke \& Feist 1985). Traditional histopathological detection of $B$. ostreae is insensitive partly for this reason. With FISH, even a small number of $B$. ostreae cells stand out from the host tissue background because, in a section, they alone are stained. Thus, FISH is more sensitive. 

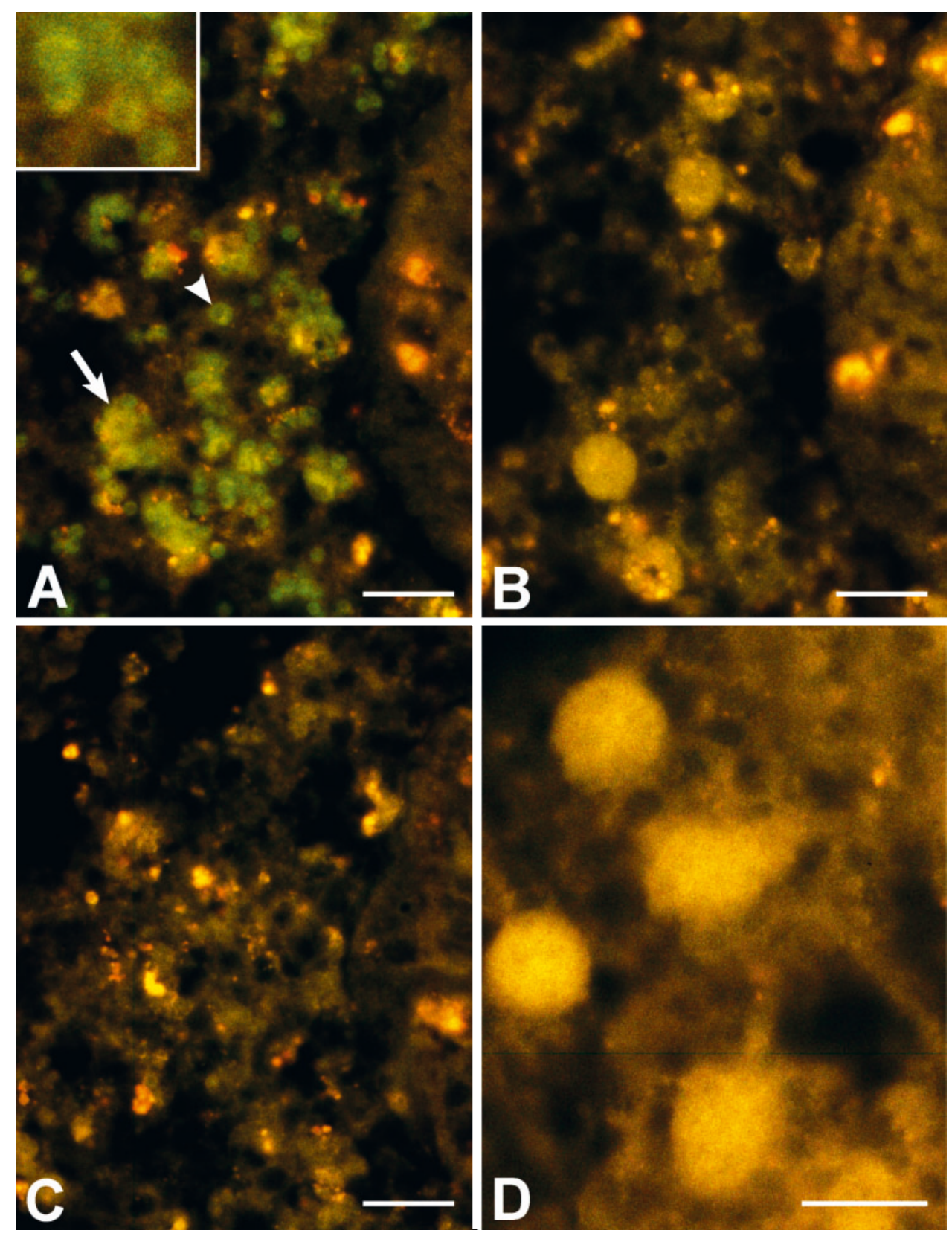

Fig. 1. Photomicrographs of the fluorescent in situ hybridization (FISH) trials (scale bars $=20 \mu \mathrm{m}$ ). (A) to (C) are serial images of hemocytes aggregated at the gut wall of a Bonamia ostreae-infected flat oyster (A) B. ostreae-specific probe treatment. Green rings indicate specific binding of the $B$. ostreae-specific probes to parasite cells. Arrowhead indicates 1 individual $B$. ostreae cell; arrow indicates a cluster of cells. Inset: Detail of $B$. ostreae cells. Note the dark eccentric areas representing $B$. ostreae cell nuclei. (B) No probe treatment, indicating the level of background autofluorescence in the absence of probes. (C) Mismatched probe treatment. A cocktail of probes mismatched to target 2 positions failed completely to bind to B. ostreae target. (D) Haplosporidium nelsoni (MSX) control. B. ostreae-specific probes failed to bind to MSX plasmodia, the 4 areas of intense yellow autofluorescence surrounded by Crassostrea virginica hemocytes

FISH provided a phylogenetic confirmation of the pathogen's identity that histopathology could not. The mismatched probe control indicated that the experimental (presumptively Bonamia ostreae-specific) probes hybridized to very specific target sequences.
The absence of hybridization in the Haplosporidium nelsoni control indicated that these target sequences might be unique to $B$. ostreae. (In a partial SSU rDNA sequence for $B$. exitiosus that appeared on GenBank [AF337563] after this work was done, one probe bind- 
ing site was identical to $B$. ostreae, while another matched $B$. ostreae at only $11 / 15$ positions. The sequence at the third binding site was unknown, but weak cross-hybridization to $B$. exitiosus should occur because of the single perfectly matched probe.) Thus, in the northern hemisphere where no other Bonamia spp. are known to occur, this FISH assay should not generate false positive results by cross-hybridization. This is significant for 2 reasons. First, as $H$. nelsoni advances northward (Ford \& Tripp 1996, Barber et al. 1997), it may eventually co-occur with $B$. ostreae in the northeastern USA. Second, the Pacific oyster Crassostrea gigas parasite Mikrocytos mackini, while not a haplosporidian (Hine et al. 2001), is indistinguishable from B. ostreae at the light microscope level (Farley et al. 1988), and infects Ostrea edulis in British Columbia, Canada where C. gigas and $O$. edulis are cultured together (Bower et al. 1997).

The specificity of this FISH assay, therefore, should compare favorably to Bonamia ostreae-specific PCRs (Carnegie et al. 2000, Cochennec et al. 2000). This assay is more specific than the $B$. ostreae-specific ISH described by Cochennec et al. (2000), which crossreacted with both Bonamia sp. (now Bonamia exitiosus) from New Zealand and Haplosporidium nelsoni. The sensitivity of this FISH relative to PCR awaits validation. While FISH may be less sensitive than PCR, it should also generate fewer false positive results, because a positive signal can be validated in terms of tissue location and cell morphology. The degree of host response can also be determined with FISH, but not with PCR. In contrast, low cost and high throughput are the PCR's strongest advantages.

Bonamia ostreae is directly transmissible between oysters in a population (Elston et al. 1987). Infections probably begin when oyster hemocytes phagocytose $B$. ostreae cells that have penetrated the gill epithelium or digestive tract. The parasite proliferates in these hemocytes and disperses throughout the oyster. With eventual necrosis and death of the host, $B$. ostreae passes via the water column to nearby oysters, and the cycle begins anew (Bucke 1988, Montes et al. 1994). This hypothesized life cycle may be tested using FISH. Prepatent infections may be detected without the visual cues (e.g. host response) that permit location of $B$. ostreae in H\&E-stained sections. Cryptic forms may be identified as well. $B$. ostreae-specific probe hybridization to objects of unexpected size or shape or in an unusual tissue location may reveal the presence of cryptic or noncanonical B. ostreae cell types. Here fluorescent ISH is particularly powerful. Probe signal is very precisely localized in FISH because the fluorescent probes may be directly observed (Schwarzacher \& Heslop-Harrison 2000). Thus, morphological charac- teristics of a stained object may be described more completely than if a chromogenic ISH were used.

This FISH assay is a powerful tool for detecting Bonamia ostreae. It sensitively identifies $B$. ostreae cells in situ. It provides a degree of morphological resolution that will expedite the search for cryptic parasite forms and resolution of the parasite's life cycle. Its primary weakness is low throughput. However, it is faster than chromogenic ISH assays for Haplosporidium nelsoni (Fong et al. 1993, Stokes \& Burreson 1995), Minchinia teredinis (Stokes et al. 1995), and Marteilia refringens (Le Roux et al. 1999) because it requires fewer post-hybridization steps. It has great potential to advance our understanding of $B$. ostreae and improve our management of the parasite in wild and cultured flat-oyster populations.

Acknowledgements. The work reported in this manuscript was supported in part by the Maine/New Hampshire Sea Grant Program and by the Northeastern Regional Aquaculture Center at the University of Massachusetts Dartmouth, through Grant No. 96-38500-3032 from the Cooperative State Research, Education, and Extension Service (CSREES) of the United States Department of Agriculture (USDA). We thank Nancy Stokes for slides of Crassostrea virginica and for generous and helpful advice regarding ISH approaches. Dawna Beane prepared the Ostrea edulis slides for histopathology and the FISH, and Dave Whitaker helped construct Fig. 1. This is Maine Agricultural and Forest Experiment Station external publication No. 2623.

\section{LITERATURE CITED}

Balouet G, Poder M, Cahour A (1983) Haemocytic parasitosis: morphology and pathology of lesions in the French flat oyster, Ostrea edulis L. Aquaculture 34:1-14

Barber BJ, Davis CV (1994) Prevalence of Bonamia ostreae in Ostrea edulis populations in Maine. J Shellfish Res 13:298

Barber BJ, Langan R, Howell T (1997) Haplosporidium nelsoni (MSX) epizootic in the Piscataqua River Estuary (Maine/New Hampshire, USA). J Parasitol 83:148-150

Bower SM, McGladdery SE, Price IM (1994) Synopsis of infectious diseases and parasites of commercially exploited shellfish. Annu Rev Fish Dis 4:1-199

Bower SM, Hervio D, Meyer GM (1997) Infectivity of Mikrocytos mackini, the causative agent of Denman Island disease in Pacific oysters Crassostrea gigas, to various species of oysters. Dis Aquat Org 29:111-116

Bucke D (1988) Pathology of bonamiasis. Parasitol Today 4(6): $174-176$

Bucke D, Feist S (1985) Bonamiasis in the flat oyster, Ostrea edulis, with comments on histological techniques. In: Ellis $\mathrm{AE}$ (ed) Fish and shellfish pathology. Academic Press, London, p 387-392

Burreson EM (2000) Disease diagnosis by PCR: foolproof or foolhardy? J Shellfish Res 19(1):642

Burreson EM, Stokes NA, Friedman CS (2000) Increased virulence in an introduced pathogen: Haplosporidium nelsoni (MSX) in the eastern oyster Crassostrea virginica. J Aquat Anim Health 12:1-8

Carnegie RB, Barber BJ, Culloty SC, Figueras AJ, Distel DL 
(2000) Development of a PCR assay for detection of the oyster pathogen Bonamia ostreae and support for its inclusion in the Haplosporidia. Dis Aquat Org 42(3):199-206

Cochennec N, Le Roux F, Berthe F, Gérard A (2000) Detection of Bonamia ostreae based on small subunit ribosomal probe. J Invertebr Pathol 76:26-32

Comps M, Tige T, Grizel H (1980) Etude ultrastructural d'un protiste parasite de l'huitre plate Ostrea edulis L. CR Acad Sci Paris 290(D):383-384

Culloty SC, Mulcahy MF (1996) Season-, age-, and sexrelated variation in the prevalence of bonamiasis in flat oysters (Ostrea edulis L.) on the south coast of Ireland. Aquaculture 144:53-63

Dubilier N, Giere O, Distel DL, Cavanaugh CM (1995) Characterization of chemoautotrophic bacterial symbionts in a gutless marine worm (Oligochaeta, Annelida) by phylogenetic 16S rRNA sequence analysis and in situ hybridization. Appl Environ Microbiol 61(6):2346-2350

Elston RA, Farley CA, Kent ML (1986) Occurrence and significance of bonamiasis in European flat oysters Ostrea edulis in North America. Dis Aquat Org 2:49-54

Elston RA, Kent ML, Wilkinson MT (1987) Resistance of Ostrea edulis to Bonamia ostreae infection. Aquaculture 64:237-242

Farley CA, Wolf PH, Elston RA (1988) A long-term study of 'microcell' disease in oysters with description of a new genus, Mikrocytos (g. n.), and two new species, Mikrocytos mackini (sp. n.) and Mikrocytos roughleyi (sp. n.). Fish Bull 86(3):581-593

Fong D, Chan MMY, Rodriguez R, Chen CC, Liang Y, Littlewood DTJ, Ford SE (1993) Small subunit ribosomal RNA gene sequence of the parasitic protozoan Haplosporidium nelsoni provides a molecular probe for the oyster MSX disease. Mol Biochem Parasitol 62:139-142

Ford SE, Tripp MR (1996) Diseases and defense mechanisms. In: Kennedy VS, Newell RIE, Eble AF (eds) The eastern oyster Crassostrea virginica. Maryland Sea Grant College, University of Maryland System, College Park, MD, p 581-660

Friedman CS, Perkins FO (1994) Range extension of Bonamia ostreae to Maine, USA. J Invertebr Pathol 64:179-181

Friedman CS, McDowell T, Groff JM, Hollibaugh JT, Manzer D, Hedrick RP (1989) Presence of Bonamia ostreae among populations of the European flat oyster, Ostrea edulis Linné, in California, USA. J Shellfish Res 8(1):133-137

Hine PM, Cochennec-Laureau N, Berthe FCJ (2001) Bonamia exitiosus n.sp. (Haplosporidia) infecting flat oysters Ostrea chilensis in New Zealand. Dis Aquat Org 47:63-72

Katkansky SC, Dahlstrom WA, Warner RW (1969) Observations on survival and growth of the European flat oyster,

Editorial responsibility: Albert Sparks,

Seattle, Washington, USA
Ostrea edulis, in California. Calif Fish Game 55(1):69-74

Le Roux F, Audemard C, Barnaud A, Berthe F (1999) DNA probes as potential tools for the detection of Marteilia refringens. Mar Biotechnol 1:588-597

McArdle JF, McKiernan F, Foley H, Jones DH (1991) The current status of Bonamia disease in Ireland. Aquaculture 93:273-278

Montes J, Villalba A, Lopez MC, Carballal MJ, Mourelle SG (1991) Bonamiasis in native flat oysters (Ostrea edulis L.) from two intertidal beds of the Ortigueira estuary (Galicia, NW Spain) with different histories of oyster culture. Aquaculture 93:213-224

Montes J, Anadón R, Azevedo C (1994) A possible life cycle for Bonamia ostreae on the basis of electron microscopy studies. J Invertebr Pathol 63:1-6

Perkins FO (1990) Phylum Haplosporidia. In: Margulis L, Corliss JL, Melkonian M, Chapman DJ (eds) Handbook of Protoctista. Jones and Bartlett Publishers, Boston, MA, p $19-29$

Pichot Y, Comps M, Tige G, Grizel H, Rabouin MA (1980) Recherches sur Bonamia ostreae gen. n., sp. n., parasite nouveau de l'hûitre plate Ostrea edulis L. Rev Trav Inst Peche Marit 43(1):131-140

Schwarzacher T, Heslop-Harrison P (2000) Practical in situ hybridization. Springer-Verlag, New York

Shaw BL, Battle HI (1957) The gross and microscopic anatomy of the digestive tract of the oyster Crassostrea virginica (Gmelin). Can J Zool 35:325-347

Stokes NA, Burreson EM (1995) A sensitive and specific DNA probe for the oyster pathogen Haplosporidium nelsoni. J Eukaryot Microbiol 42(4):350-357

Stokes NA, Siddall ME, Burreson EM (1995) Small subunit ribosomal RNA gene sequence of Minchinia teredinis (Haplosporidia: Haplosporidiidae) and a specific DNA probe and PCR primers for its detection. J Invertebr Pathol 65:300-308

Stokes NA, Flores BS, Burreson EM, Alcox KA, Guo X, Ford SE (1997) Life cycle studies of Haplosporidium nelsoni (MSX) using PCR technology. J Shellfish Res 16(1):336

Trembleau A, Bloom FE (1995) Enhanced sensitivity for light and electron microscopic in situ hybridization with multiple simultaneous non-radioactive oligodeoxynucleotide probes. J Histochem Cytochem 43(8):829-841

van Banning P (1985) Control of Bonamia in Dutch oyster culture. In: Ellis AE (ed) Fish and shellfish pathology. Academic Press, London, p 393-396

Zabaleta AI, Barber BJ (1996) Prevalence, intensity, and detection of Bonamia ostreae in Ostrea edulis L. in the Damariscotta River area, Maine. J Shellfish Res 15(2):395-400

Submitted: March 16, 2002; Accepted: February 15, 2003

Proofs received from author(s): July 4, 2003 